Linguistik Terapan 17 (3) (2020): 235-241.

Jurnal Linguistik Terapan Pascasarjana

Available online

http://jurnal.unimed.ac.id/2019/index.php/JLT-Unimed

\title{
THE USE OF LETTERLAND STRATEGIES \\ IN TEACHING ENGLISH VOCABULARY TO YOUNG LEARNERS
}

\author{
Julianti \\ Rahmad Husein \\ Anni Holila Pulungan \\ English Aplied Linguistic Program \\ Postgraduate Program-Universitas Negeri Medan
}

Diterima September 2020; Disetujui Oktober 2020; Dipublikasikan Desember 2020

\begin{abstract}
The purpose of this research was to help teachers to enrich their knowledge about Letterland strategies in teaching English vocabulary to young learners. The objective of this research was to investigate the types of problem faced by teachers while using Letterland strategies. This research applied descriptive qualitative design and the data gathered from the sentences of four teachers in Nursery class at a Singapore Pre-School, Medan. The techniques of collecting data were observation and interview. Then, the techniques in analyzing the data were condensation, data display, and conclusion drawing/verification. Based on the data analysis, it was found that there were two types of problem faced by all the teachers; an internal disturbance $(54.55 \%)$, and an external disturbance $(45.45 \%)$. It was concluded that Letterland strategies were good for young learners in learning English vocabulary because it provided some fun activities that contained of multi-sensory based learning which they were able to see, hear, do, and touch it.
\end{abstract}

Keywords: English Vocabulary; Letterland Strategies; Young Learners

How to Cite: Julianti. (2020. The Use of Letterland Strategies in Teaching English Vocabulary to Young Learners. Jurnal Linguistik Terapan-Pascasarjana Unimed. 17(3): $235-241$.

ISSN: 2407 - 7410

\section{INTRODUCTION}

In Indonesia, English is a foreign language where adults, teenagers, or young learners learn it. Learning vocabulary is the most important thing to learn a language. People will know better about the meaning of the language if they master the vocabulary (Lelawati, Dhiya, and Mailani, 2018:95). 
Vocabulary is a main component of language proficiency and it provides much of the basis for how well young learners can speak, listen, read, and write. In conveying and sharing opinion by oral and written, vocabulary plays a great impact for students (Isnaniah, 2018:302).

The skills of listening, speaking, reading, and writing will be easier to be performed if the learners have a lot of vocabularies. Nowadays, English has been taught earlier to young learner in Indonesia (Syafrizal, and Haerudin, 2018:40). Through teaching English vocabulary to young learner, there are four skills that will be mastered. They are listening, speaking, reading and writing.

Teachers have the important role to build children's vocabularies. In order to teach young learner, teachers are required to be more creative (Pushpanathan, 2017:53), so the young learners will enjoy the lesson which finally the objectives of the teaching and learning process will be successful.

The term of 'young learner' is increasingly employed to cover children studying English from as early as 3 years old all the way up until the age of 13-14 (Rich, 2014:2). Moreover, Lelawati, et.al (2018:96) said that young learners are children from the first year of formal schooling ( 5 or 6 years old) to eleven or twelve years old.

Young learners' learning moods is not stable every other minute, they make themselves difficult to sit still. That is why the teacher should be more creative in choosing materials and able to stimulate the student's interest. As we know how important the vocabulary is, so the teacher should make sure that the teaching strategy that is going to apply is able to help them in learning English vocabulary easier.

People play important roles in helping children to learn, bringing objects and ideas to their attention, then talking while playing and about playing, reading stories, and asking question. Moreover, adults mediate the children's world and make it able to be accessed to them. With the adults' help, children are able to do and understand much more than they can on their own.

In the process of teaching and learning, teachers will be faced some problems or it can be said that there are things can go wrong at the time. Scott, and Ytreberg (1990:104) stated that there are several types of things can go wrong. They are an external disturbance, an internal disturbance, the class is out of control, an activity is taking too long, you have extra time, an activity doesn't work, and an activity is too difficult.

However, teachers have to be more patient and creative in facing young learners in teaching. Conducting fun learning way and choosing appropriate teaching strategy in 
teaching English vocabulary to young learners will be an effective idea. Then, teachers have to know how to make nice atmosphere during the teaching learning process in order to attract their attention.

Yaver (2003) said that Letterland concept of an invisible, secret place called Letterland, located somewhere in the written word and inhabited by fictional animals and people, created by the British educator, Lyn Wendon in 70s. The basic mission of Letterland is to ensure that young learners have fun in learning English. It can be used for young learners for 3 to 8 years old where the emphasis is on having fun, thus young learner may absorb learning naturally. It provides a secure learning environment where young learners can happily develop cognitive, language and literacy skills.

Moreover, it can be concluded that Letterland is a learning strategy represented by an imaginary place (wonderland) where each letter is a character built around its shape (a pictogram) represented by people and animals, with a name that uses the sound the letter makes (alliteration) with a friendly environment for young learners to have fun during teaching learning process.

However, Letterland is still new in Indonesia that is why many teachers do not know what it is. So, this research will help teachers to enrich their knowledge about what problems faced while teaching Letterland strategies so they can handle it.

\section{METHOD}

This research applied descriptive qualitative research design which the data were the sentences from teachers consisting of the types of problem faced by them. The source of the data were four teachers in the Nursery class. The teacher's names were MC, MD, MA, and MM.

The teachers were the subjects of this research because they were teachers who teach at the level Nursery class which the students were three to four years old that represented the young learners. Then, they had Letterland class which was taught for three to four years old students.

The data were collected by using observation and interview technique (Ary, Jacobs, and Sorensen, 2010:431). In observation, it used video recording and field notes to get the data when the teachers used the Letterland. Next, in interview, semi or partially structured interview type was used which the questions were formulated but the interviewer could modify the format or questions during the interview process. 
Moreover, it was conducted by applying some procedures in order to collect the data. They were taking video recording while the teacher was teaching English vocabulary by using the Letterland strategies, making field notes referred to the Letterland strategies used by the teacher, recording when the teacher was being interviewed, making field notes when the teacher was being interviewed.

There were three activities that applied in analyzing the data proposed by Miles, Huberman, and Saldana (2014:31). They are data condensation, data display, and conclusion drawing/verification. Then, in making the trustworthiness of this research, it applied audit trail (Ary, et.al, 2010:502).

Audit trail provides a mechanism by which others can determine about how the decisions were made and the uniqueness of the situation. Then, it documents about how the research was conducted, including what was done, when, and why. It includes the raw data gathered in interviews, and observations. It kept the notes and records of all the activities. Then, the data were kept in well organized. Moreover, it was provided information about the subject, the selection process, contextual descriptions, methods of data collection, detailed field notes, video recordings, interview recordings, and other descriptive materials that were reviewed.

In order to check and review the findings of the research, it was opened all the documents of the research that had been kept in well organized before such as the data of the types of problem faced by teachers while using Letterland strategies in teaching English vocabulary to young learners, the data collection (Observation and interview), the methods, etc. Then, all the data taken from the interview and observation (The teachers' sentences taken during the teaching learning process and interview time), and other descriptive materials (The guided interview questions and field notes) were checked and reviewed to make sure all of them still focus and related each other.

\section{FINDINGS AND DISCUSSIONS}

In teaching learning process, some of teachers got some problems to teach their students. There are some types of problem that faced by teachers when they teach young learners, such as external disturbance, an internal disturbance, the class is out of control, an activity is taking too long, extra time, an activity doesn't work, and an activity is too difficult. Then, the percentages of the problems were shown in the Table 1. 
Table 1. The Total Percentages of Types of Problem Faced by Teachers

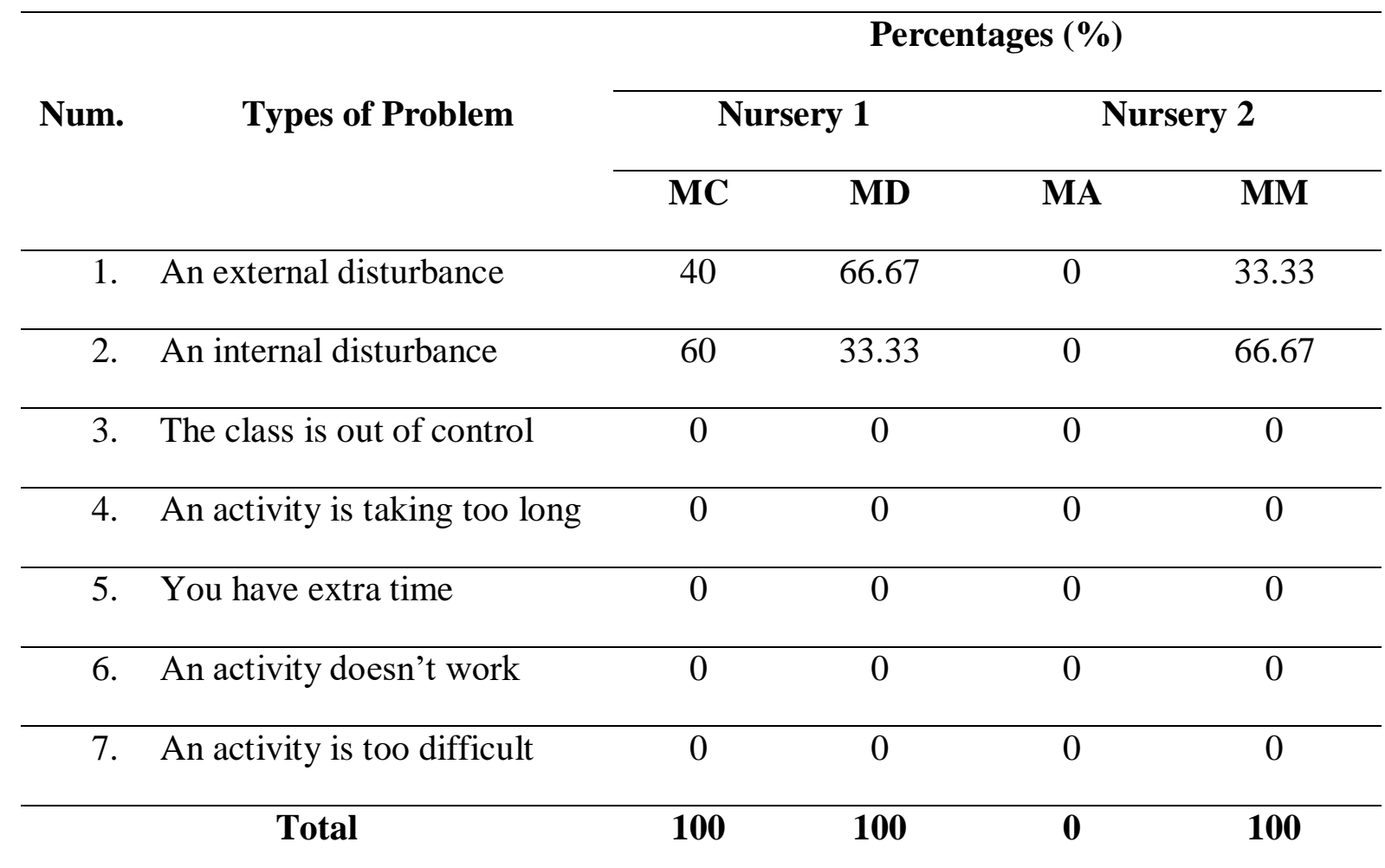

From the Table 1, it showed that MC got $40 \%$ for the external disturbance problems and for the internal disturbance was $60 \%$. It meant the internal disturbance problems were dominant for the teacher MC. In other side, MD got the percentage of the external disturbance problems $(66.67 \%)$ higher than the internal disturbance problems $(33.33 \%)$. The problems that came from outside were dominant for the teacher MD. So, the types of problem from MC and MD were different in the percentages because they had different students and problems that they faced during the teaching learning process.

Furthermore, MA did not have any problem applying the Letterland strategies during the teaching learning process. MM got $33.33 \%$ for the external disturbance problems and for the internal disturbance was $66.67 \%$. It meant that MM got the highest percentage for the internal disturbance rather than the external disturbance. For MA, she was only one teacher that said there was no problems that she faced while teaching EYL during the teaching learning process. She was okay and everything run well in her class.

Comparing Nursery 1 with Nursery 2, Nursery 2 was better than Nursery 1 . In Nursery 2 class, the teachers got less problems during teaching learning process in teaching young learners. It was considered because of their students were four years old. They listened and knew well what the teachers said in giving instructions or explaining the lesson. Otherwise, in Nursery 1 , the teachers got more problems during the teaching learning process 
about the disturbance that they got in teaching young learners. Their students were three years old that still needed more guidance, and time to know that they had to study at school. That's why the teachers from Nursery 1 got more problems rather than the teachers from Nursery 2.

Then, from all teachers only found the types of problem external and internal disturbance during teaching learning process by using Letterland strategies. The other problems, such as the class is out of control, an activity is taking too long, extra time, an activity doesn't work, and an activity is too difficult weren't be found. It meant that their problems while teaching English vocabulay to young learners only external and internal problems.

\section{CONCLUSIONS}

The types of problem faced by the teachers while using the Letterland strategies in teaching English vocabulary to young learners were an external disturbance, and an internal disturbance. It was found only two types of problem from seven problems based on the theory that faced by the teachers. So, it could be concluded that the Letterland strategies are good for the young learners.

Then, For the problem an external disturbance, it was found that MD got the highest percentage from the others. She got $66.67 \%$, followed by MC that got 40\%, MM got 33.33\%, and MA got $0 \%$ for the problem. For the problem an internal disturbance, MM got the highest percentage of the others. She got $66.67 \%$, followed by MC that got $60 \%$, MD got $33.33 \%$, and MA got $0 \%$ for the type of problem. Furthermore, from the two types of problem that found from all the teachers, an internal disturbance was the higher percentage $(54.55 \%)$ compared than an external disturbance $(45.45 \%)$.

Moreover, the teachers are suggested to be able to handle their students during the teaching learning process. They have to be creative and get a lot of ideas to make their students can focus on them during the teaching learning process. They should be able to solve the happening problem as soon as possible, then they continue the lesson directly at the time. So, it can be minimized the problems that they faced while they are teaching the English vocabulary to the young learners. Next, they also need to manage their time. They should think to not waste the time when solving the problem. They have to manage time effectively. So, it hoped the goals of the lesson can be achieved at the time. 
Then, school management has to check their facilities regularly that usually used by the teachers. So, it will not be found anymore if one of the facilities doesn't work when the teachers are using it in the teaching learning process.

\section{REFERENCES}

Ary, D., L. C. Jacobs, \& C. Sorensen. (2010). Introduction to Research in Education. USA: Wadsworth, Cengage Learning.

Isnaniah. 2018. Using Letterland as Child Friendly Technique in Teaching English Vocabulary For Young Learners. Proceeding of International Conference On ChildFriendly Education, 301-305.

Lelawati, S., S. Dhiya, \& P. N. Mailani. 2018. The Teaching of English Vocabulary to Young Learners. Professional Journal of English Education, 95-100.

Miles, M. B., A. M. Huberman, \& J. Saldana. (2014). Qualitative Data Analysis: A Methods Sourcebook. USA: SAGE Publications, Inc.

Pushpanathan, T. 2017. A Review of Vocabulary Teaching Techniques for Young Learners. Research Demagogue, 53-56.

Rich, Sarah. 2014. International Perspectives on Teaching English to Young Learners. UK: Palgrave Macmillan.

Scott, W. A., \& L. H. Ytreberg. (1990). Teaching English to Children. New York: Longman Keys to Language Teaching.

Syafrizal, \& Haerudin. 2018. The Implementation of Vocabulary Building Strategy in Teaching English Vocabulary to Young Learners. Journal of English Language Teaching, 40-48.

Yaver, O. Y. 2003. Letterland Pictogram Concept in EFL Teaching of Young Children. The Internet TESL Journal. Vol. IX, No. 3. 